\title{
PENINGKATAN BRAND IMAGE (CITRA MEREK) DALAM RANGKA PENGEMBANGAN PRODUK AGROINDUSTRI KERING KENTANG (Studi Kasus pada Kering Kentang "Kirana” di KabupatenTuban)
}

\author{
Silvana Maulidah, Heru Santoso HS, Fahmi Yudhi F. *) \\ *) Fakultas Pertanian, Jurusan Sosial Ekonomi - Agribisnis, Universitas Brawijaya. \\ E-mail: silvana.maulidah@yahoo.com
}

\begin{abstract}
This research purpose it is to analyze: (1) The expectations of consumers towards agro-industry brand image; (2) Analyze improvement planning of brand image in order to development of agro-industry keringkentangkiranaproducts. The method used in this study is a instrument variables test, descriptive analysis and qualitative analysis.Descriptive analysis aims to describe the facts, or population or certain areas with factual and systematic. Analysis qualitative in this study is using Quality Function Deployment QFD, from stage 1 to stage 4. The result showed that: ( 1 ) Consumer expectations of the brand image attributes that need to be improved and become a first priority for repaired is legal, advertising, durability, packaging, and logo design with a value of 0,10. For the second attributes that must guarded and maintained by the company is the price and the taste with the value 0,096, while the third priority is the aroma, texture, color and brand name with a normal weight of 0,077. ( 2 ) Planning and improvement in brand image in order to development KeringKentangKirana, performed by observing the production plan that have the highest importance weight values to be prioritized and addressed by CV Putra Mandiri Perkasa within development of KeringKentangKirana, first production planning is standardize the production process with a value of 2,04, raw material selection with a value 1,796, packaging design and logo with a value 1,755, and the latter is an extension of ads with a value 1,491.
\end{abstract}

Keywords : Brand Image, Product development, Quality Function

\begin{abstract}
Abstrak: Penelitian ini bertujuan untuk: (1) Menganalisis harapan konsumen (suarasuara pelanggan) terhadap Brand Image agroindustri kering kentang kirana; (2) Menganalisis perencanaan peningkatan Brand Image dalam rangka pengembangan produk agroindustri kering kentang kirana. Metode penelitian yang digunakan dalam penelitian ini adalah uji instrumen variabel, analisis deskriptif dan analisis kualitatif. Analisis deskriptif bertujuan untuk melukiskan fakta, populasi atau bidang tertentu secara factual dan sistematis. Analisis kualitatif menggunakan metode Quality Function Deployment QFD, dari tahap 1 hingga tahap 4. Dari hasil penelitian didapatkan bahwa : (1) Harapan konsumen terhadap atribut brand image yang perlu ditingkatkan dan menjadi prioritas utama untuk diperbaiki adalah legalitas, iklan, daya tahan, kemasan, dan desain logo dengan nilai 0,10. Atribut yang menjadi prioritas kedua adalah harga dan rasa dengan nilai 0,096 untuk dijaga dan dipertahankan oleh perusahaan, sedangkan yang menjadi prioritas ketiga adalah aroma, tekstur, warna dan nama merek dengan bobot normal 0,077. (2) Urutan prioritas rencana produksi pertama yaitu standarisasi proses produksi 2,047, pemilihan bahan baku 1,796, desain kemasan dan logo 1,755, dan yang terakhir adalah perluasan iklan 1,491.
\end{abstract}

Kata kunci : Brand Image, Pengembangan produk, Quality Function Deployment 


\section{PENDAHULUAN}

Indonesia memiliki peluang dan prospek yang cerah untuk mengembangkan sektor pertanian. Salah satu sektor pertanian yang bergerak pada pengolahan pangan biasa disebut dengan Agroindustri. Agroindustri berasal dari dua kata agricultural dan industry yang berarti suatu industry yang menghasilkan suatu produk yang digunakan sebagai sarana atau input dalam usaha pertanian (Kusnandar, 2010).

Produk agroindustri yang memiliki daya tarik akan bahan baku, proses produksi, bentuk produk dan permintaannya adalah agroindustri dengan bahan baku kentang, karena kentang (SolanumtuberosumL.) merupakan salah satu pangan utama dunia setelah padi, gandum dan jagung. Kentang juga merupakan komoditi unggulan sayuran yang bernilai tinggi dan sampai saat ini masih terus diusahakan di Indonesia secara komersial sebagaimana terlihat pada Tabel 1.

Dari Tabel 1 bisa dilihat bahwa produksi kentang dari tahun 2009 mengalami fluktuatif peningkatan hingga tahun 2012, teapi pada tahun 2012 produksi kentang mangalami kenaikan yang cukup tinggi. Produksi kentang di wilayah Jawa Timur pada tahun 2012 mencapai hingga 162.306 Ton dengan produktivitas 15,59 Ton/Ha (BPS, 2012). Produksi kentang yang mengalami kenaikan cukup tinggimembutuhkan penanganan pasca panen yang tepat. Produksi kentang yang tinggi diwilayah Jawa Timur memberikan peluang kepada pengusaha agar dapat mengembangkan agroindustri berbahan baku kentang.

Kabupaten Tuban merupakan salah satu kabupaten di Jawa Timur yang mempunyai industri pengolahan makanan berbahan baku kentang. Perusahaan yang mengolah kentang menjadi produk olahan makanan yang berada di kabupaten Tuban yaitu CV. Putra Mandiri Perkasa. CV. Putra Mandiri Perkasa merupakan perusahaan yang mengolah kentang menjadi produk olahan makanan yaitu kering kentang dengan merek kirana. Kering kentang kirana merupakan makanan yang dapat dijadikan sebagai camilan dan lauk yang praktis dan efesien, sehingga produk tersebut berpotensi untuk menjadi produk olahan berbahan baku kentang yang banyak diminati konsumen.

Namun, kering kentang kirana masih memerlukan pengenalan dan perbaikan pada produk untuk menjadi produk yang diminati oleh konsumen, banyak sekali yang harus diperhatikan oleh produsen untuk memperkenalkan dan memperbaiki produk. Citra merek (brand image) dapat dianggap sebagai jenis asosiasi yang muncul di benak konsumen ketika mengingat sebuah merek tertentu. Menurut Knap (2001), asosiasiasosiasi merek dapat membantu konsumen dalam memproses informasi tentang suatu merek.

Karakteristik agroindustri yang memiliki kontak interaksi tinggi dengan konsumen ini membutuhkan strategi tersendiri. Peningkatan brand image menjadi satu alternatif agar perusahaan mampu mencapai target penjualan yang ditetapkan perusahaan serta mampu bertahan dan bersaing dengan perusahaan agroindustri lainnya berdasarkan brand image yang sudah melekat pada konsumen. Perlunya peningkatan brand image pada produk agroindustri kering kentang dikarenakan masih belum begitu dikenalnya produk agroindustri kering kentang di kalangan konsumen luas, pemasaran yang belum optimal, serta perlunya peningkatan kualitas produk berdasarkan

Tabel 1. Produksi Kentang Indonesia 2009-2012

\begin{tabular}{ccclccc}
\hline Tahun & $\begin{array}{l}\text { Luas } \\
(\mathrm{Ha})\end{array}$ & $\begin{array}{r}\text { Panen Produktivitas } \\
(\text { Ton/Ha) }\end{array}$ & $\begin{array}{l}\text { Produksi } \\
(\text { Ton })\end{array}$ & \multicolumn{3}{c}{ Kenaikan Atau Penurunan } \\
\cline { 5 - 6 } & 71.238 & 16.51 & 1.176 .304 & - & $\begin{array}{l}\text { Produktivitas } \\
(\%)\end{array}$ & $\begin{array}{l}\text { Produksi } \\
(\%)\end{array}$ \\
\hline 2009 & 66.531 & 15.94 & 1.060 .805 & -6.60 & -3.42 & -9.81 \\
2011 & 59.882 & 15.96 & 955.488 & -9.99 & -0.12 & -9.92 \\
2012 & 65.989 & 16.58 & 1.094 .240 & 10.19 & 4.01 & 14.52 \\
\hline
\end{tabular}

Sumber : Badan Pusat Statistik dan Direktorat Jenderal Hortikultura, Departemen Pertanian, 2012 
Silvana M., Heru Santoso HS, Fahmi Y. F. : Peningkatan brand image (citra merek)...

Membuat konsumen untuk lebih mengenal dan memilih produk kering kentang kirana dirasa perlu dilakukan, dengan memenuhi atribut-atribut untuk meningkatkan brand image yang sesuai dengan keinginan konsumen, untuk pengembangan produk yang benar-benar sesuai dengan keinginan konsumen.

Tujuan dari penelitian ini adalah (1) Menganalisis harapan konsumen terhadap Brand Image agroindustri kering kentang. (2) Menganalisis perencanaan peningkatan Brand Image dalam rangka pengembangan produk agroindustri kering kentang.

\section{METODE PENELITIAN}

Pemilihan lokasi dilakukan secara (purposive), dengan pertimbangan bahwa agroindustri kering kentang sangatlah berpotensi untuk dikembangkan karena agroindustri kering kentang kirana merupakan agroidustri pertama di Kota Tuban yang memproduksi kering kentang dan berprospek untuk dikembangkan.

Responden dalam peneliian ini terdapat dua responden yaitu responden yang berasal dari perusahaan dan dari konsumen. Penentuan responden yang pertama yaitu secara purposive untuk responden perusahaan dan non probability sampling dengan accidental sampling untuk penentuan responden konsumen.

Jumlah sampel yang digunakan sebagai responden adalah 40 orang. Penentuan sampel berdasarkan pertimbangan menurut Sugiyono (2010), bahwa ukuran sampel yang layak dalam suatu penelitian adalah minimal 30 untuk sampel yang diambil secara random. Pemilihan jumlah responden dilebihkan dari jumlah minimal untuk distribusi normal, menghindari homogenitas data, serta tidak adanya jumlah populasi dari konsumen kering kentang untuk dihitung.

Metode pengumpulan data yang dilakukan selama pelaksanaan penelitian ini adalah dengan mengumpulkan data sesuai dengan obyek dan tujuan penelitian. Data yang dikumpulakn berupa data primer dan sekunder, data primer yang diambil berupa wawancara dengan perusahaan serta pernyebaran kuisioner. Data sekunder diperoleh dari beberapa literature dan instansi terkait.
Hasil wawancara kuisioner dengan konsumen akan ditindaklanjuti oleh perusahaan melalui respon perusahaan dari kemampuan perusahaan berdasarkan wawancara dengan perusahaan. Perusahaan akan menentukan hubungan tiap respon teknis dengan part kritis, kemudian part terpilih akan dicari hubungan dengan proses produksi dengan wawancara perusahaan. Proses produksi terpilih akan ditentukan hubungannya oleh perusahaan melalui wawancara untuk mendapatkan prioritas rencana produksi yang digunakan untuk pengembangan produk.

Analisis data dilakukan dengan uji instrument dan analisis secara kualitatif. Uji instrument dimana didalamnya terdapat uji validitas dan uji reabilitas. Uji Validitas digunakan untuk mengukur sah atau valid tidaknya suatu kuisioner. Suatu kuisioner dinyatakan valid jika pertanyaan pada kuisioner mampu mengungkapkan sesuatu yang akan diukur oleh kuisioner tersebut (Imam Ghozali, 2005). Suatu variabel dikatakan reliable atau handal jika jawaban seseorang terhadap pernyataan adalah konsisten atau stabil dari waktu ke waktu (Imam Ghozali, 2005). Uji validitas dan reabilitas dilakukan dengan bantuan alat spss 16.0 .

Analisis kulitatif yang dilakukan dalam penelitian ini menggunakan metode Quality Function Deployment (QFD). Analisis QFD yang dilakukan pada tahap pertama hanya menghasilkan sebuah House of Quality (rumah kualitas), pada tahap kedua menghasilkan matrik Part/ design deployment (desain pengembangan), pada tahap ketiga menghasilkan matrik Process Planning (rencana produksi), dan pada tahap keeempat menghasilkan matrik Production Planning (rencana produksi).

Pada analisis QFD tahap 1, langkahlangkah untuk menyusun House of Quality adalah dengan menyusun harapan dari pelanggan kering kentang kirana, setelah itu menentukan matriks perencanaan yang berisi tingkat kepentingan pelanggan, tingkat kepuasan pelanggan terhadap produk "kering kentang kirana" dengan pesaing produk "mini stick kentang pedas", kemudian menentukan sasaran, menentukan nilai penjualan, rasio perbaikan serta nilai bobot dan bobot normal. Menentukan respon teknis dari CV Putra Mandiri Perkasa berdasarkan dari kebutuhan 
pelanggan, setelah itu didapatkan hubungan atribut harapan pelanggan dengan respon teknis perusahaan, dan menentukan hubungan antar respon teknis, sehingga terakhir didapatkan matriks prioritas untuk respon teknis. Gambar 1. Menunjukan bentuk matriks HOQ pada produk kering kentang kirana serta urutan pelaksanaannya.

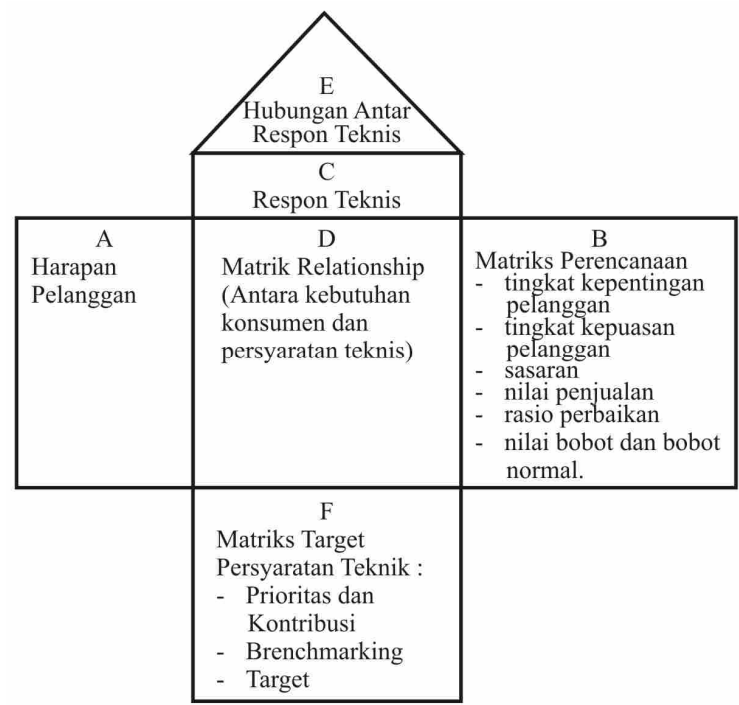

Gambar 1. Matrik $H o Q$ kering kentang kirana

Setelah tahap penyusunan matriks HOQ tahap selanjutnya adalah penyusunan matriks design deployment atau Part/ design deployment. tindakan pertama dalam penyusunan matrik part/design deployment adalah menentukan respon teknis terpilih dari $H o Q$, kemudian menentukan spesifikasi part kritis, menentukan nilai kepentingan, menanyakan hubungan antar keduanya, menghitung bobot kepentingan.

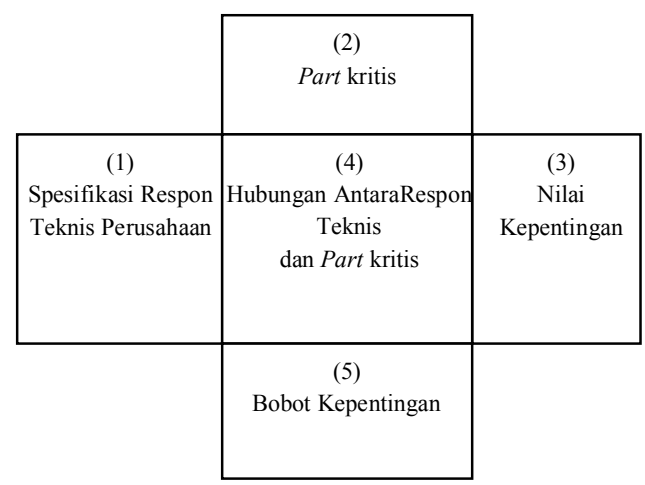

Gambar 2. Matrik Part/design deployment kering kentang kirana
Tahap ketiga adalah penyusunan matriks process planning. Tindakan pertama dalam penyusunan matrik process planning adalah menentukan part kritis terpilih terpilih dari part/design deployment, kemudian menentukan spesifikasi proses produksi, menentukan nilai kepentingan, menanyakan hubungan antar keduanya, dan menghitung bobot kepentingan.

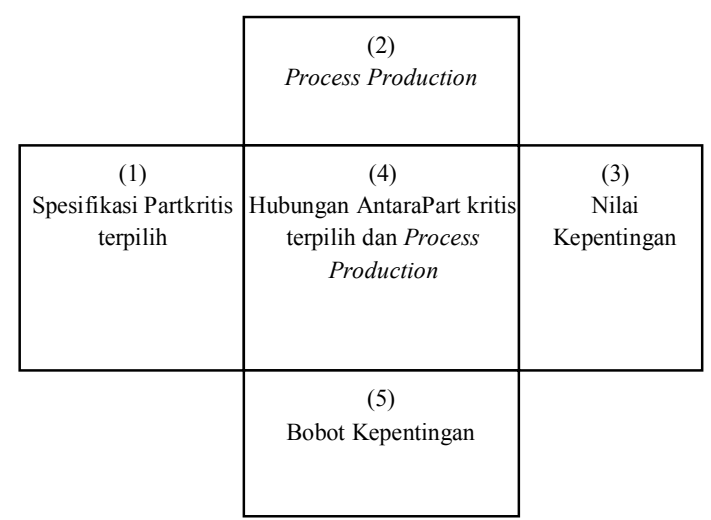

Gambar 3. Matrik Process Planning kering kentang kirana

Tahap terakhir adalah penyusunan matriks production planning. Tindakan pertama dalam penyusunan matrik production planning adalah menentukan part kritis terpilih dari process planning, kemudian menentukan spesifikasi rencana produksi, menentukan nilai kepentingan, menanyakan hubungan antar keduanya, serta menghitung bobot kepentingan. Hasilnya maka didapatkanlah prioritas rencana produksi dari perusahaan untuk mengembangkan produk.

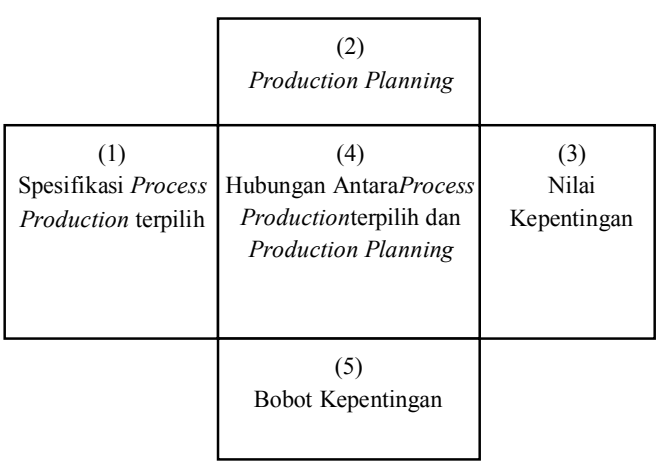

Gambar 4. Matrik Production Planning kering kentang kirana. 
Silvana M., Heru Santoso HS, Fahmi Y. F. : Peningkatan brand image (citra merek)...

\section{HASIL DAN PEMBAHASAN}

Hasil uji instrumen penelitian meliputi uji validitas dan uji reliabilitas dengan bantuan software SPSS 16.0, maka diperoleh hasil uji validitas dan reliabilitas.Pada tabel diatas dapat diketahui bahwa semua atribut mempunyai nilair hitung yang lebih besar dari r-tabel $(0,308)$. Sehingga instrument kepentingan pelanggan dianggap valid, serta instrument kepuasan pelanggan, yang dimana semua nilai $r$ hitung lebih besar dari r-tabel. Dari tabel diatas dapat disimpulkan bahwa semua instrument yang dipakai dalam penelitian ini dianggap valid, karena hasil perhitungan $r$ hitung $>r$ tabel.

Dari Tabel 3 dapat dilihat bahwa instrument kepentingan pelanggan mempunyai nilai alpha cronbach yang lebih dari 0,6 yang menunjukkan instrument tersebut reliabel. Begitu pula dengan instrument kepuasan kkk, dengan kkb yang nilai alpha cronbach juga lebih dari 0,6, nilai ini menunjukkan bahwa nilai instrument yang digunakan dalam penelitian ini reliabel, sehingga dapat menghasilkan data yang konsisten jika dilakukan peneliatan ulang.

Hasil penelitian dengan judul peningkatan brand image dalam rangka pengembangan produk kering kentang terdapat dua tujuan. Tujuan pertama menganilisis harapan konsumen terhadap brand image agroindustri kering kentang, untuk tujuan kedua pada penelitian ini adalah menganilisis perencanaan peningkatan brand image dalam rangka pengembangan produk.

Tabel 2. Uji Validitas

\begin{tabular}{|c|c|c|c|c|c|}
\hline \multicolumn{6}{|c|}{$\mathrm{n}=40 ;$ Taraf Significant $5 \% ; \mathrm{r}$-Tabel $=0,308$} \\
\hline \multirow{3}{*}{ No. } & \multirow{3}{*}{ Atribut } & \multirow{3}{*}{$\begin{array}{l}\text { r-tabel } \\
\text { Kepentingan } \\
\text { Pelanggan } \\
\end{array}$} & \multirow{2}{*}{\multicolumn{2}{|c|}{ Kepuasan }} & \multirow{3}{*}{ Valid } \\
\hline & & & & & \\
\hline & & & KKK & MKP & \\
\hline 1. & Harga & 0,655 & 0,532 & 0,631 & Ya \\
\hline 2. & Legalitas & 0,635 & 0,647 & 0,518 & Ya \\
\hline 3. & Iklan & 0,558 & 0,512 & 0,627 & Ya \\
\hline 4. & Daya Tahan & 0,685 & 0,496 & 0,427 & Ya \\
\hline & Rasa & 0,585 & 0,583 & 0,565 & Ya \\
\hline 6. & Aroma & 0,795 & 0,68 & 0,536 & Ya \\
\hline 7. & Tekstur & 0,647 & 0,722 & 0,344 & Ya \\
\hline 8. & Warna & 0,694 & 0,532 & 0,604 & $\mathrm{Ya}$ \\
\hline & Kemasan & 0,69 & 0,422 & 0,392 & Ya \\
\hline & Nama Merek & 0,694 & 0,439 & 0,542 & Ya \\
\hline 11. & Desain Logo dan Gambar & 0,727 & 0,384 & 0,499 & Ya \\
\hline
\end{tabular}

Sumber : Data Primer di olah (2014)

Tabel 3. Uji Reliabilitas

\begin{tabular}{lcc}
\hline \multicolumn{3}{c}{ Alpha Cronbach $>0,6$} \\
\hline No. Instrument & $\begin{array}{c}\text { Nilai Alpha } \\
\text { Cronbach }\end{array}$ & Reliabel \\
\hline 1. Kepentingan Pelanggan & 0,877 & Ya \\
2. Kepuasan KKK & 0,736 & Ya \\
3. Kepuasan MKP & 0,727 & Ya \\
\hline
\end{tabular}

Sumber : Data primer diolah (2014) 
Silvana M., Heru Santoso HS, Fahmi Y. F. : Peningkatan brand image (citra merek)...

Tabel 4. Harapan Konsumen

\begin{tabular}{|c|c|c|}
\hline No. & Atribut & Harapan konsumen \\
\hline \multirow{4}{*}{$\begin{array}{ll}\text { 1. } & \text { Kekuatan } \\
& \text { (Strength) }\end{array}$} & Harga & Rp $10.000-R p 15.000$ \\
\hline & Legalitas & BPOM \\
\hline & Iklan & Iklan Melalui Internet \\
\hline & Daya Tahan & 1-3 Bulan \\
\hline \multirow{5}{*}{$\begin{array}{l}\text { 2. Keunikan } \\
\text { (Uniqueness) }\end{array}$} & Rasa & Pedas Manis \\
\hline & Aroma & Jahe \\
\hline & Tekstur & Renyah \\
\hline & Warna & Kemasan \\
\hline & Kemasan & Alumunium Foil \\
\hline \multirow{2}{*}{ 3. Favorable } & Nama Merek & Gampang Diingat \\
\hline & Desain Logo dan Gambar & Warna Terang dan Logo Kecil \\
\hline
\end{tabular}

Sumber : Data Primer di olah (2014)

Analisis Harapan Konsumen Terhadap Brand Image Produk Kering Kentang

Tujuan pertama yaitu menganalisis harapan konsumen terhadap brand image agroindustri kering kentang kirana, dimana harapan konsumen terhadap brand image agroindustri kering kentang dibatasi pada brand image produk kering kentang.

Analisis harapan konsumen terhadap brand image produk kering kentang kirana akan dilakukan dengan bantuan matrik HoQ, dimana di dalamnya terdapat penyusunan persyaratan pelanggan, dan matrik perencanaan. Matrik ini akan memprioritaskan persyaratan pelanggan sesuai dengan harapan dari pelanggan untuk ditanggapi dan diperbaiki dengan respon teknis oleh perusahaan nantinya.

Dari hasil pengamatan dan survei maka didapat kriteria persyaratan pelanggan yang terdiri dari kekuatan, keunikan dan favorable produk kering kentang. Atribut yang dipilih merupakan atribut yang digunakan untuk meningkatkan brand image produk yang akan berguna dalam rangka pengembangan produk.

Harapan pelanggan yang belum sesuai dengan produk akan direspon dan diperbaiki perusahaan melalui respon teknis.

\section{Matrik Perencanaan}

Matrik perencanaan adalah bagian kedua pada dari House of Quality dan disebut sebagai tempat penentuan sasaran/ tujuan produk, didasarkan pada interpretasi terhadap data yang telah diisi oleh responden. Matrik perencanaan berisi dalam hal ini mitingkat kepentingan konsumen, tingkat kepuasan konsumen, sasaran, rasio perbaikan, poin penjualan, nilai bobot dan bobot normal.

Berdasarkan survey terhadap konsumen didapatkan bahwa prosentase terbanyak konsumen menilai bahwa atribut harga berupa satuan nilai yang diberikan pada suatu komoditi sebagai informasi dari produsen, yang harus dikeluarkan oleh konsumen untuk mendapatkan produk kering kentang, iklan, daya tahan, Rasa,aroma merupakan hasil kerja dari indra pencium yang dapat membentuk persepsi tentang aroma produk kering kentang. Munculnya aroma merupakan hal yang paling kuat untuk memicu otak dalam mengingat sesuatu sebagai identitas produk kering kentang., tekstur yang merupakan kualitas tertentu suatu permukaan sekaligus merupakan nilai raba pada permukaan produk kering kentang baik itu nyata maupun semu, selanjutnya, warna yang menarik dan mengundang selera, kemasan, nama merek dan desain logo penting bagi produk kering kentang. Tingkat kepuasan pelanggan bagi pelanggan diketahui dari survei terhadap 40 responden. Hasil survei kemudian dianalisis dengan menggunakan tabulasi deskriptif berupa tabel frekuensi. Didapatkan produk kering kentang kirana unggul pada atribut rasayang merupakan hasil kerja indra pengecap rasa atau bagian dari cita rasa yang dianggap enak,harga yang terjangkau dan nama merek yang mampu melekat di benak konsumen, artinya responden puas terhadap atribut rasa dan hargapada produk kering kentang Kirana dibandingkan 
dengan produk pesaing dalam hal ini mini stick kentang pedas.

Produk kering kentang kirana mempunyai nilai yang sama yaitu puas untuk atribut aroma, tekstur dan warna terhadap produk mini stick kentang pedas. Hal ini berarti tingkat kepuasan responden terhadap atribut sama, yaitu puas untuk ketiga atribut tersebut. Responden merasa puas untuk atribut iklan, daya tahan, legalitas, kemasan dan logo pada produk mini stick kentang pedas, dan hanya merasa cukup puas pada produk kering kentang kirana.

Tingkat kepuasan pelanggan terhadap produk mini stick kentang pedas mempunyai nilai yang cukup baik dibanding kering kentang kirana. Hal ini membuat kering kentang kirana perlu meningkatkan beberapa atribut yang masih kurang baik dibanding produk mini stick kentang pedas.

Sasaran merupakan nilai yang dibuat untuk memutuskan nilai dari kinerja yang ingin dicapai dalam memenuhi kebutuhan konsumen. Sasaran pada atribut harga, rasa, aroma, tekstur, warna dan nama merek perlu dipertahankan karena nilai sasaran yang diperoleh sama dengan nilai tingkat kepuasan pada produk kering kentang kirana. Sedangkan untuk atribut legalitas, iklan, daya tahan, kemasan dan desain logo pada produk kering kentang kirana diperlukan peningkatan karena nilai kepuasannya masih dibawah dari nilai sasaran yang diperoleh

Rasio Perbaikan adalah rasio antara nilai sasaran yang diterapkan manajemen perusahaan dengan tingkat kepuasan persyaratan pelanggan perusahaan yang dinilai oleh pelanggan. Atribut peningkatan brand image seperti Legalitas, Iklan dan daya tahan membutuhkan usaha yang lebih besar dikarenakan nilai rasio perbaikan pada atribut tersebut cukup besar. Nilai rasio perbaikan ditujukan untuk memperbaiki atribut yang perlu ditingkatkan karena mempunyai nilai kepuasan dibawah nilai sasaran.

Poin penjualan memberitahu seberapa baik suatu persyaratan pelanggan akan membantu penjualan dari total 40 responden, atribut yang sudah menolong dalam penjualan ialah atribut harga dan rasa, sedangkan untuk atribut yang lain masih sebatas cukup menolong dalam penjualan produk saja.
Atribut brand image yang akan ditingkatkan dan dikembangkan perlu ditentukan nilai bobot dan bobot normal terlebih dahulu. Dengan mengetahui prioritas pengembangan atribut produk, maka dapat ditentukan urutan atribut mana yang akan ditingkatkan dan dipertahankan. Atribut brand image yang perlu ditingkatkan dan menjadi prioritas utama untuk diperbaiki adalah legalitas, iklan, daya tahan, kemasan, dan desain logo dengan nilai 0,10 . Untuk atribut yang menjadi prioritas kedua adalah harga dan rasa dengan nilai 0,096 untuk dijaga dan dipertahankan oleh perusahaan, sedangkan yang menjadi prioritas ketiga adalah aroma, tekstur, warna dan nama merek dengan bobot normal 0,077 .

\section{Perencanaan Peningkatan Brand Image Dalam Rangka Pengembangan Produk Kering Kentang}

Tujuan kedua dalam penelitian yaitu menganalisis perencanaan peningkatan brand image dalam rangka pengembangan agroindustri kering kentang, dimana harapan konsumen terhadap brand image agroindustri kering kentang yang sudah terdapat pada matrik HoQ akan dibuat acuan untuk respon teknis perusahaan.

Setelah mengetahui persyaratan pelanggan terhadap produk kering kentang kirana, perusahaan kemudian menerjemahkan persyaratan pelanggan tersebut ke dalam Respon Teknis. Respon Teknis yang diperoleh melalui wawancara dengan manajer CV. Putra Mandiri Perkasa berdasarkan harapan dari pelanggan dapat dilihat pada Tabel 4 .

Berdasarkan wawancara dengan Manajer CV. Putra Mandiri Perkasa, hubungan antara persyaratan pelanggan dengan respon teknis/ kemampuan perusahaan. Contoh hubungan kuat terjadi antara pemilihan baku bekualitas dengan harga, legalitas, dan rasa. Contoh hubungan yang sedang terjadi antaran daya tahan dengan perubahan kemasan. Persyaratan pelanggan yang tidak memiliki hubungan sama sekali adalah nama merek dengan pemilhan bahan baku berkualitas.

Berdasarkan tabel hubungan antar respon teknis pada CV. Putra Mandiri Perkasa didapat beberapa hubunganpositif kuat dan lemah. antar persyaratanteknik yang memiliki hubungan 
positif kuat adalah perubahan kemasan dengan perluasan iklan melalui internet.

Nilai prioritas merupakan perhitungan perkalian bobot normal dengan nilai hubungan antara persyaratan pelanggan dan respon teknis. Nilai prioritas akan mempresentasikan bagaimana kontribusi respon teknis terhadap harapan konsumen, sedangkan kontribusi merupakan presentase dari nilai prioritas dengan range $0-1$.

Respon teknis yang perlu ditingkatkan pertama adalah pemilihan bahan baku, kedua proses produksi, kemudian perluasan iklan setelah itu perubahan kemasan produk, barulah yang terakhir pembuatan desain logo produk. Respon teknis yang mempunyai priorotas dan kontribusi tinggi sangat perlu ditingkatkan untuk memenuhi harapan konsumen yang tujuannya kepada pengembangan produk.

Brenchmarking merupakan perhitungan perkalian antara kepuasan pelanggan dengan matrik hubungan antara harapan konsumen dan respon teknis perusahaan. Nilai target menggambarkan bagaimana respon teknis yang harus dicapai sesuai dengan kebutuhan konsumen serta performansi dari pesaing.

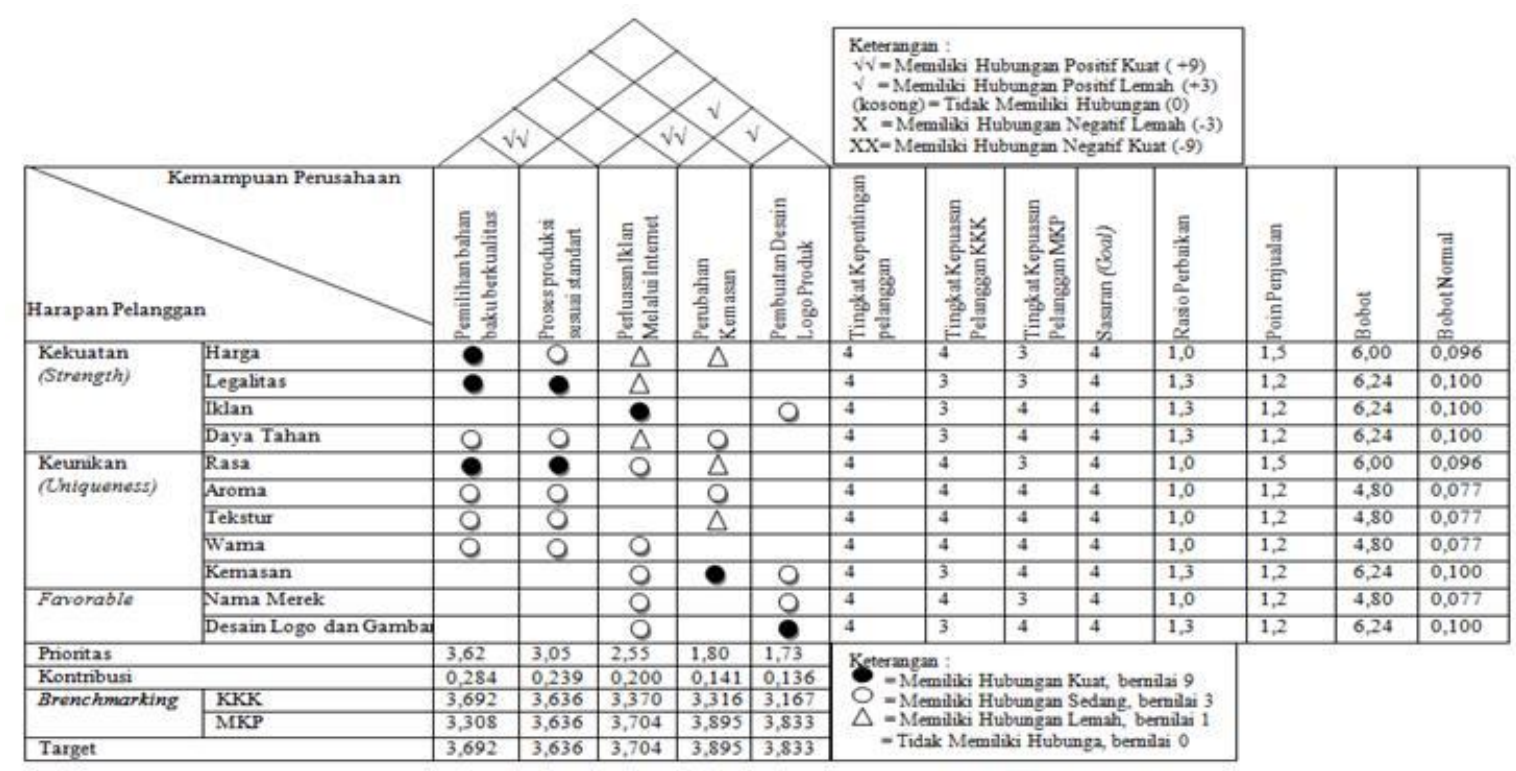

Gambar 5. Matriks House of Quality

Sumber : Data Primer di olah (2014)

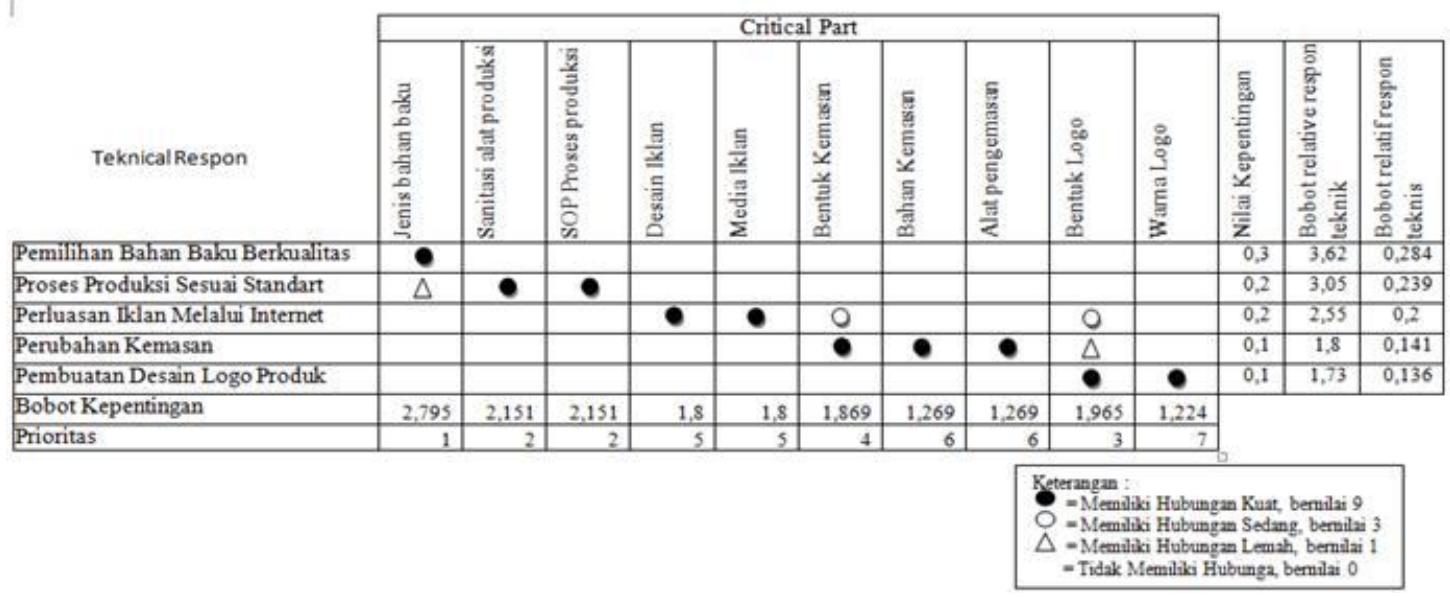

Gambar 6. Matrik Part/Design Deployment

Sumber : Data Primer di olah (2014) 
Silvana M., Heru Santoso HS, Fahmi Y. F. : Peningkatan brand image (citra merek)...

Berdasarkan nilai target dan prioritas respon teknis maka dapat diketahui pemilihan bahan baku menjadi prioritas pertama untuk dipertahankan, sedangkan yang kedua yaitu proses produksi.Perluasan iklan merupakan respon teknis yang mempunyai prioritas ketiga untuk lebih ditingkatkan, respon teknis perubahan kemasan berada pada prioritas keempat, serta yang terakhir untukditingkatkan adalah pembuatan desain logo.Semua matrik perencanaan dan hubungan antar respon teknis dan atribut serta data target dimasukkan ke dalam matrik $H o Q$. Setelah tahap penyusunan matriks HOQ tahap selanjutnya adalah penyusunan matriks design deployment atau Part/Design Peployment.

Pada Gambar 6. matrik Part/Design Peployment didalamnya terdapat nilai kepentingan, nilai kontribusi dan prioritas yang terdapat pada $H o Q$.

Pada matrik Part/Design Peployment ditunjukan hubungan antara part kritis dengan respon teknis, hubungan yang terjadi antara respon teknis dan part kritis adalah hubungan kuat, sedang, lemah dan tidak memiliki hubungan. Contoh hubungan kuat ditunjukkan antara bentuk kemasan dan bahan kemasan dengan respon teknis perubahan kemasan, bentuk Salah satu hubungan sedang adalah antara part kritis bentuk kemasan dengan perluasan iklan, bentuk. Untuk contoh hubungan lemah antara jenis bahan baku dengan proses produksi, jenis, sedangkan part kritis dan respon teknis yang tidak memiliki hubungan salah satunya adalah antara jenis bahan baku dengan pembuatan desain logo produk.

Berdasarkan perhitungan pada matrik Part/Design Peployment didapatkan nilai bobot kepentingan dengan cara mengkalikan nilai hubungan antara respon teknis dengan part kritis. Part kritis jenis bahan baku memiliki bobot kepentingan paling tinggi sehingga di prioritaskan pertama dalam hal ini. Ciri bahan baku (kentang) yang berkualitas ialah kulit umbi kentang tidak mudah terkelupas atau lecet, berkulit mulus, bertekstur padat serta tidak mempunya retakan di masing-masing sisinya. Selanjutnya ialah part kritis sanitasi alat produksi dan SOP proses produksi mempunyai bobot kepentingan yang sama, dan prioritas yang sama pula, part kritis selanjutnya sesuai dengan bobot kepentingan dan prioritas dibawahnya adalah bentuk logo, bentuk kemasan, desain iklan, media iklan, bahan kemasan, alat pengemasan, dan warna logo.

Setelah penyusunan matriks design deployment, dilanjutkan dengan penyusunan matriks process planning atau matriks perencanaan proses. Sebelum menentukan matrik proses, harus diperhatikan tiap tahap proses produksi kering kentang.

Pada Gambar7. matrik process planning didalamnya terdapat nilai kepentingan, part kritis terpilih, proses produksi, hubungan proses produksi dan part kritis terpilih serta bobot kepentingan.

Pada matriks process planning akan diketahui hubungan antara part kritis terpilih dengan critical process requirement. Hubungan yang ditunjukkan adalah hubungan kuat, medium, lemah serta tidak memiliki hubungan.

Berdasarkan bobot kepentingan yang dihitung dari perkalian nilai hubungan dengan nilai bobot relatif, dapat diketahui urutan prioritas rencana proses yangharus diperhatikan oleh CV. Putra Mandiri Perkasa dalam berdasarkan bobot kepentingan proses. Urutan prioritas rencana proses dimulai dari penyedian bahan baku berkualitas, proses penjualan, bahan baku kemasan, waktu masak tumis bumbu, cara pengadukan pencampuran bahan, proses pemasaran, proses pengemasan, kemudian proses penggorengan bahan baku, dilanjut pemotongan bahan baku dan penghalusan bumbu, diteruskan dengan proses pengupasan, pendinginan kering kentang serta waktu pencampuran bahan dan terakhir proses pengiriman.

Setelahurutan prioritas semua rencana proses diprioritaskan untuk dilakukan kemudian pihak CV. Putra Mandiri Perkasa memprioritaskan lagi beberaparencana proses yang hanya memiliki bobotkepentingan proses terbesar untuk dimasukkan kedalam matrik production planning.

Tahap terakhir dari pembuatan matriks QFD adalah penyusunan matriks Production Planning atau matriks perencanaan proses produksi. Menurut Widodo (2003), tahap perencanaan produksi merupakan tahap terakhir untuk mengetahui tindakan yang perlu diambil untuk perbaikan performa perancangan produk. 


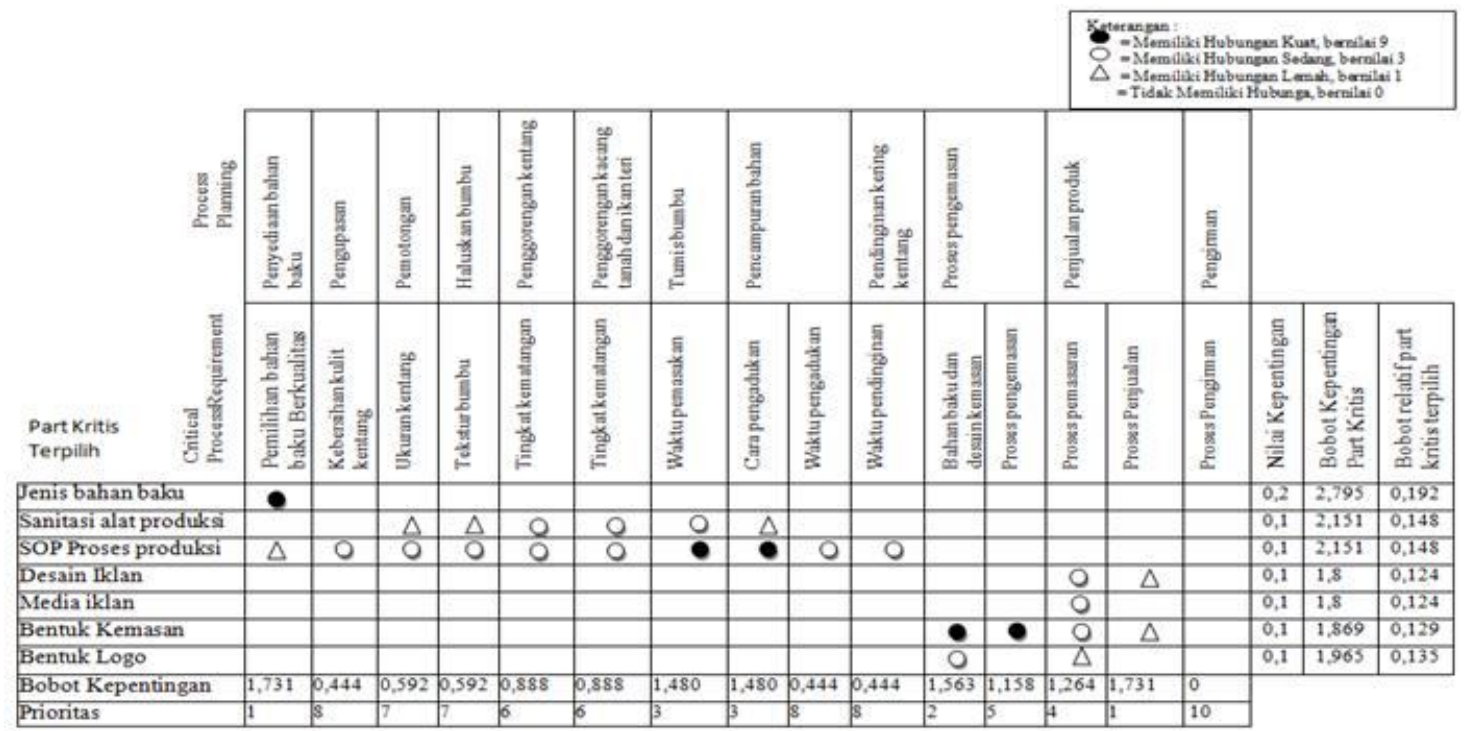

Gambar 7. Matrik Process Planning

Sumber: Data primer diolah (2014)

Standarisasi proses produksi menjadi prioritas pertama bagi perusahaan untuk membuat proses produksi sesuai standar serta dapat berjalan optimal. Proses produksi yang berjalan dengan optimal dan sesuai prosedur dimulai dari pemilihan kentang yang baik, pencucian hingga bersih, pemberian bumbu sesuai takaran, penggorengan, sampai dengan pengepakan yang higienis akan menghasilkan produk akhir kering kentang yang berkualitas dalam hal ini aroma, rasa dan teksturnya cocok atau sesuai dengan harapan konsumen .

Pada matriks production planning akan diketahui hubungan antara proses produksi terpilih dengan rencana produksi. Hubungan yang ditunjukkan adalah hubungan kuat, medium, lemah serta tidak memiliki hubungan.
Berdasarkan bobot kepentingan yang dihitung dari perkalian nilai hubungan dengan nilai bobot relatif, dapat diketahui urutan prioritas rencana proses produksi. Dari bobot kepentingan akan didapatkan prioritas untuk production planning. Production planning yang mempunyai bobot kepentingan tertinggi adalah standarisasi proses produksi, pemilihan bahan baku, desain kemasan dan logo, dan yang terakhir adalah perluasan iklan.

Dengan mengerjakan keempat rumah kualitas ini yaitu matriks house of quality, matriks design deployment, matriks process planning dan matriks production planning maka lengkaplah seluruh proses perancangan dengan menggunakan metode QFD.

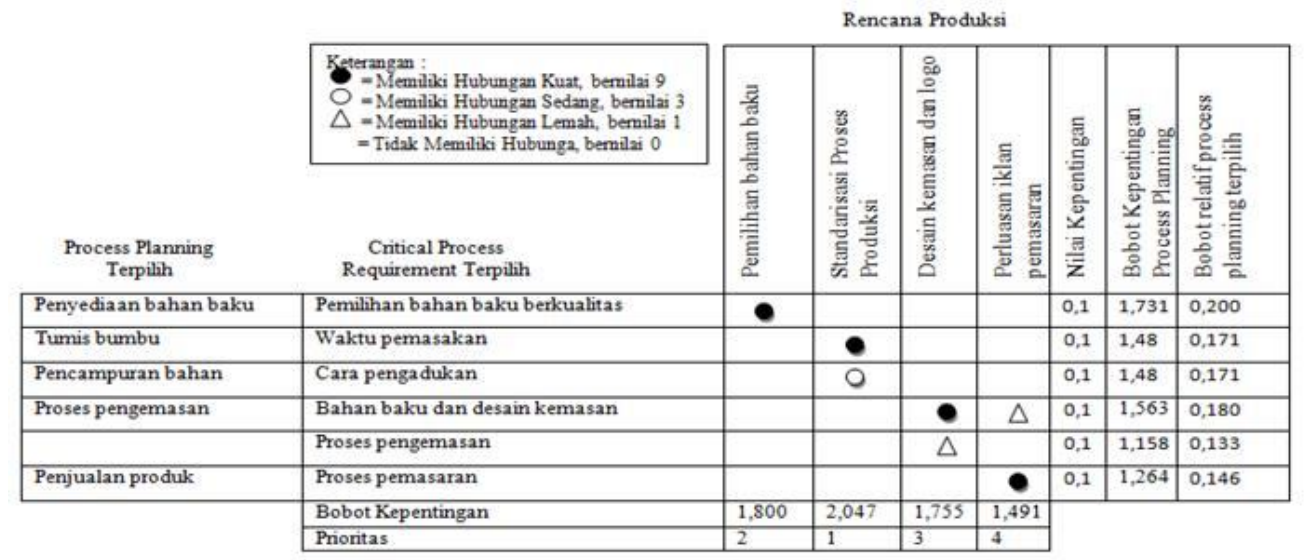

Gambar 8. Matrik Production Planning

Sumber: Data primer diolah (2014) 
Tahap demi tahap akan menunjukan bagaimana proses interpretasi dan analisis perancangan disusun secara sistematis. Keinginan konsumen yang diterjemahkan kedalam bahasa teknis (rumah pertama) kemudian dikembangkan dalam rumah kedua (matriks design deployment) menghasilkan perbaikan-perbaikan rancangan bagian produk. Pada gambar matrik production planning didalamnya terdapat nilai kepentingan, bobot kepentingan dan bobot relatif dari proses terpilih. Nilai kepentingan spesifikasi part menempati posisi disebelah kanan matriks production planning. Nilai kepentingan digunakan untuk usaha prioritasdan membuat keputusan hubungan antar respon teknis. Nilai kepentingan menggambarkankepentingan setiap spesifikasi proses terpilih bagi perusahaanuntuk menghasilkan rencana produksi yang diharapkan. Nilai kepentingan diperoleh dari rasio antara bobot kepentingan dengan total bobot kepentingan pada matriks process planning. Nilai kepentingan yang diperoleh proses terpilih semua sama yaitu 0,1 .

Dalam penyusunan matriks production planning yang dilakukan adalah membandingkan antara proses terpilih dengan rencana produksi, kemudian menentukan hubungan mereka masing- masing. Setiap proses terpilih mungkin mempengaruhi lebih dari satu rencana produksi, dan sebaliknya. Dalam menentukan hubungan antara proses terpilih dengan rencana produksi digunakan matriks hubungan. Matriks hubungan ini menyusun bagian tengah dalam matriks production planning.

Hubungan yang terjadi proses terpilih dengan rencana produksi dapat merupakan hubungan yang kuat, sedang atau lemah. Selain itu, mungkin saja tidak ada hubungan antara proses terpilih dengan rencana produksi. Berdasarkan survey dan wawancara terhadap CV Putra Mandiri Perkasa,diketahui hubungan antara proses terpilih dengan rencana produksi.

Berdasarkan matriks production planning didapat beberapa hubungan. Contoh hubungan kuat terjadi antara bahan baku dan desain kemasan dengan desain kemasan dan logo. Hal ini dikarenakan bahan baku dan desain kemasan harus diperhatikan dalam pembuatan desain kemasan dan logo maupun proses pengemasan, karena akan memberikan dampak untuk membuat produk lebih menarik serta menarik perhatian dari konsumen.

Contoh hubungan sedang terjadi antara proses memasak tumis bumbu dengan standarisasi proses produksi. Proses memasak dipengaruhi oleh standarisasi proses produksi, meskipun tidak terlalu kuat dan significant pengaruhnya. Sedangkan untuk hubungan lemah terdapat pada proses pemasaran dengan desain kemasan dab logo produk, desain logo produk dapat membantu proses pemasaran meskipun hanya berpengaruh kecil.

Langkah terakhir dalam penyusunan matriks production planning adalah menentukan bobot kepentingan produksi dan kontrol. Nilai bobot kepentingan produksi dan kontrol diperoleh dengan cara mengalikan antara nilai bobot relative rencana proses terpilih dengan nilai hubungan antara rencana proses terpilih dengan rencana produksi

Berdasarkan bobot kepentingan, dapat diketahui urutan prioritas rencana produksi yangharus diperhatikan oleh CV. Putra Mandiri Perkasa dalam peningkatan brand image guna mengembangkan produk Kering Kentang Kirana berdasarkan bobot kepentingan, urutan prioritas rencana produksi dimulaidari rencana proses yang memiliki bobot kepentingan proses terbesar sampai dengan rencana proses yang memilki bobot kepentingan proses terkecil. Setelahurutan prioritas semua rencana produksi diprioritaskan untuk dilakukan kemudian pihak CV. Putra Mandiri Perkasa memprioritaskan lagi beberaparencana produksi yang hanya memiliki bobotkepentingan yang cukup besar.

Pada matrik production planning dapat diketahui nilai bobot kepentingan setiap rencana produksi yang berasal dari penjumlahan perkalian antara nilai hubungan dengan bobot relatif proses produksi terpilih. Dari bobot kepentingan akan didapatkan prioritas untuk production planning. Production planningyang mempunyai bobot kepentingan tertinggi adalah standarisasi proses produksi, pemilihan bahan baku, desain kemasan dan logo, dan yang terakhir adalah perluasan iklan.

Standarisasi proses produksi menjadi prioritas pertama bagi perusahaan karena proses produksi yang berjalan dengan optimal dan sesuai prosuder akan menghasilkan produk akhir kering kentang yang berkualitas dan sesuai dengan harapan konsumen . 
Silvana M., Heru Santoso HS, Fahmi Y. F. : Peningkatan brand image (citra merek)...

Ketepatan pemilihan baku menjadi prioritas perusahaan kedua untuk menjaga bahan baku sebelum digunakan produksi. Ketepatan pemilihan bahan baku dikarenakan bisa mempengaruhi proses produksi serta hasil dari produk kering kentang kirana.

Rencana produksi yang menjadi prioritas ketiga untuk perusahaan adalah desain logo dan kemasan. Hal ini dikarenakan desain logo dan kemasan merpuakan bentuk dari produk yang bisa diingat dan dikenali oleh konsumen, desain logo dan produk juga menjadikan produk akan lebih menarik dan mempunyai identitas yang dikenali oleh konsumen.

Rencana produksi yang mendapat prioritas selanjutnya adalah perluasan iklan pemasaran, perluasan iklan akan membantu memasarkan serta mengenalkan produk. Dengan perluasan iklan produk dapat lebih mudah dikenal dan dipasarkan ke konsumen. Perluasan iklan dilakukan oleh perusahaan untuk mengenalkan produk serta memberikan informasi produk terhadap konsumen. perluasan iklan melalui media sosial di internet dengan iklan yang menarik dan informatif akan membuat iklan kering kentang mudah diterima dan menarik perhatian konsumen.

Dari hasil penyusunan prioritas tersebut maka didapatkan rencana produksi dan kontrol yang terpilih dan harus diperhatikan oleh. CV. Putra Mandiri Perkasa yaitu standarisasi proses produksi, pemilihan bahan baku, desain kemasan dan logo, dan yang terakhir adalah perluasan iklan.Rencana produksi terpilih harus benar-benar diperhatikan karena memiliki prioritas dan bobot kepentingan yang tinggi.

Dengan mengerjakan keempat rumah kualitas ini yaitu matriks house of quality, matriks design deployment, matriks process planning danmatriks production planning maka lengkaplah seluruh proses perancangan denganmenggunakan metode QFD.

\section{KESIMPULAN}

Harapan konsumen terhadap brand image sesuai prioritas adalah sebagai berikut: a) Atribut yang perlu ditingkatkan dengan nilai bobot normal 0,10 antara lain adalah legalitas, iklan, daya tahan, kemasan, dan desain logo b) Atribut yang perlu dijaga dan dipertahankan dengan bobot normal 0,096 adalah harga dan rasa c) Atribut yang perlu dijaga dan dipertahankan dengan bobot normal 0,077 adalah aroma, tekstur, warna dan nama.

$$
\text { Prioritas Rencana Produksi: }
$$

Standarisasi proses produksi $(2,047)$ b) Pemilihan bahan baku $(1,800)$ c) Desain kemasan \& $\log 0(1,755)$ d) Perluasan iklan $(1,491)$.

\section{DAFTAR PUSTAKA}

BPS. 2012. www.bps.go.id. Diakses pada tanggal 25 november 2013

Ghozali, Imam. 2005. Aplikasi Analisis Multivariate dengan Program SPSS. BP Undip. Semarang.

Kusnandar, T. Mardikanto dan A. wibowo, 2010. Manajemen Agroindustri, Kajian Teori Dan Model Kelembagaan Agroindustri Skala Kecil Pedesaan. Cetakan 1. Surakarta. UNS Press.

Knap, Duance. 2002. The Brand Mind Set. Andi. Yogyakarta

Sugiyono. 2010. Metode Penelitian Kuantitatif Kualitatif dan $R \& D$. Bandung. Alfabeta.

Widodo, I.D. 2003. Perencanaan dan pengembangan Produk (Product, Planning \&design). Uji Press. Jogjakarta. 